\title{
'This is education as the practice of freedom': Twenty Years of Women's Studies at the University of Oxford
}

\author{
Charlotte De Val*, Eleri Anona Watson* \\ Address \\ *Correspondence: charlotte.deval@wadh.oxfordalumni.org; \\ eleri.watson@ell.ox.ac.uk
}

\begin{abstract}
On 23 May 2015 students on the Women's Studies Masters (M.St course) at the University of Oxford organised a conference to commemorate twenty years of Women's Studies at Oxford, entitled: "Teaching to Transgress': Twenty Years of Women's Studies at Oxford'. The conference consisted of a mixture of papers from leading academics in the field of Women's Studies, as well as from postgraduate students currently enrolled on the M.St programme at Oxford, with the intention of giving young early career women the opportunity to present their research to a broad interdisciplinary audience.
\end{abstract}

Since its foundation in 1995, the Women's Studies course has strived to enact what the American feminist and activist bell hooks terms 'education as the practice of freedom'. ${ }^{1}$ Reflecting upon the discussions emerging from the

Funding: See pages 12324.

Peer review: This article has been subject to a double blind peer review process

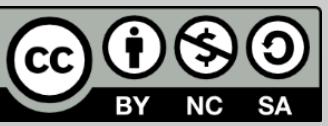

(C) Copyright: The Authors. This article is issued under the terms of the Creative Commons Attribution NonCommercial Share Alike License, which permits use and redistribution of the work provided that the original author and source are credited, the work is not used for commercial purposes and that any derivative works are made available under conference, the conference organisers Charlotte De Val and Eleri Anona Watson ask: 'what are the new and repeated challenges we face in fulfilling this practice of freedom?' They also consider the changing scope of Women's Studies as an academic field alongside present debates regarding its future in the UK and further afield. Examining debates of 'possibility' and 'impossibility' within Women's Studies-that is to say, materialist versus post-structuralist critiques-in conjunction with questions of accessibility and 'intellectual gatekeeping', this article proposes that the future of Women's Studies is not the 'apocalyptic' vision that its critics would often have us believe. Indeed, one of the themes emerging from the conference was that as long as the field practices radical self-questioning and self-critique, Women's Studies will maintain its academically and socially transformative potential.

Keywords: Women's Studies; Gender Studies; Feminism; University of Oxford; Education; Pedagogy

\footnotetext{
1 bell hooks's writings cover gender, race, teaching, education and media, emphasising the connections with systems of oppression. hooks is the author of pioneering works such as Ain't I $a$ Woman?: Black Women and Feminism (1981), Feminist Theory: From Margin to Centre (1984) and Writing Beyond Race: Living Theory and Practice (2013), and remains a leading public intellectual in feminist and educational studies.
} 


\section{Introduction}

For twenty years, the Women's Studies M.St programme at the University of Oxford has sought to challenge the academy, its research, its praxis and its ethics. Bringing together women from across the humanities, it was founded with the aim of 'teaching to transgress', consistently nurturing women to challenge notions of knowledgeproduction in a project of hermeneutic as well as social justice. ${ }^{2}$ In May 2015, we-as students enrolled on the Women's Studies programmeheld a conference to commemorate its anniversary year entitled 'Teaching to Transgress': Twenty Years of Women's Studies at Oxford. With the support of Oxford's 'Women in the Humanities' network, the conference presented the rich, interdisciplinary research that our discipline produces. Student presentations examined a diversity of topics, from 'fag hags' to female collaboration in rap, and from 'fiction of development' to women veterans and Post-Traumatic Stress Disorder. Alongside student research, keynote lectures were delivered by Patricia Hill Collins (Professor of Sociology, University of Maryland), Laura Doan (Professor of Cultural History and Sexuality Studies, University of Manchester), Jack Halberstam (Professor of American Studies and Ethnicity, Gender Studies and Comparative Literature, University of Southern California), Lucy Bolton (Senior Lecturer in Film Studies, Queen Mary, University of London) and Ros Ballaster (Professor of 18th Century Studies, Mansfield College, University of Oxford).

Yet anniversaries are a time for reflection as well as celebration. Across varied disciplines and interdisciplines, the keynote papers and the student organising committee sought to address the changing scope of Women's Studies over the last two decades as well as the on-going debates that the field faces today. In this article, we would like to take the opportunity to reflect on some of the discussions and ideas emerging from the conference about the place of Women's Studies within the academy: its inclusivity of minority women's groups and the future of Women's Studies as a discipline.

Women's Studies, as we have experienced it, is an educational practice possessing possibility - to labour for freedom, to collectively imagine and to transgress traditional academic boundaries. Feminist academics have long addressed the practice of education. The feminist public intellectual bell hooks, for example, famously described education as the 'practice of freedom'. The 'possibility' of the classroom, she argues, offers an opportunity 'to labour for freedom, to demand of ourselves and our comrades, an openness of mind and heart that allows us to face reality

\footnotetext{
2 The M.St in Women's Studies was founded in 1995 by an interdisciplinary group of Oxford
} academics. 
even as we collectively imagine ways to move beyond boundaries, to transgress' (hooks, 1994: 207). The processes and consequences of institutionalisation have been debated time and again and are perhaps best-captured in the 'impossibility/possibility' debate led by leading figures in the field of Women's Studies, Wendy Brown and Robyn Wiegman respectively (Brown, 1997; Wiegman, 2005). Today, we may ask ourselves, 'what are the new and repeated challenges we face in fulfilling this practice of freedom?' Yet, as we seek to fulfil our practice of freedom, the field remains plagued by questions about the role and aims of Women's Studies today. Rife with such debates, questions of accessibility and applicability, of theory and practice, and of 'possibility' and 'impossibility' were raised as key concerns by the keynote speakers of this event as they considered 'where next for Women's Studies?'

\section{The 'habitus' of Women's Studies in the academy}

In her opening address, Ros Ballaster (University of Oxford), a member of the original organising committee for the M.St in Women's Studies, discussed the origins of the course, the experience of institutionalisation and the place of Women's Studies in the 'field' of the academy. ${ }^{3}$ Attesting to the transgressive origins of the programme, Ballaster discussed the aims of pedagogic innovation and the concerns, felt by many feminists, about teaching in a top-down way (Ballaster, 2015). Students on the M.St course have seen this innovation play out through interdisciplinarity, as it does not have an institutionalised department and has some element of 'freedom' in being able to operate across departments, including English Literature, Modern Languages, History and Philosophy.

Drawing attention to the inherent structures and ideas that inform behaviours, Ballaster employed the notion of 'habitus', as coined by the French sociologist Pierre Bourdieu, and suggested that the institutionalisation of Women's Studies should be regarded as a work of social practice and not just an 'act of ideas'. As students on the course, we also experienced the attempts to challenge the 'top-down' studentteacher hierarchies. Our feminist theory and methodology seminars, for example, were collaborative and offered time to discuss our own experiences and knowledges outside of and in relation to the set texts.

As Ballaster went onto explain, an interdisciplinary seminar series preceded the establishment of the degree programme, which was

\footnotetext{
${ }^{3}$ R. Ballaster (2015), 'Mastering Women's Studies? Habitus and Hazards', paper presented at 'Teaching to Transgress': Twenty Years of Women's Studies at Oxford conference, Oxford, 23 May 2015. Cited as (Ballaster, 2015).
} 
principally a network that sought to foster 'private, capillary interactions' across disciplines (Ballaster, 2015). This group, Ballaster recalled with amusement, called themselves the 'Committee of Women's Studies', a self-designated identity not recognised or constituted by the university. In addition to identity-building, the institutionalisation of Women's Studies had administrative and more practical consequences. Indeed, the driving force behind the Women's Studies course was the aim to form a 'visible' and recognised structure that would enhance existing interactions between staff at Oxford. The institution of the course was, therefore, an aspiration based upon both identity and practicality. As Ballaster reflects, it was designed to provide a 'habitus' for researchers working on Women's Studies, 'a space to live, behave and interact within the field of the institution we were all employed by, within our own disciplines' (Ballaster, 2015).

Women's Studies at Oxford was thus poised to act differently to other disciplines from its inception. Through institutionalisation, Women's Studies is positioned among the hierarchies and politics of the academy that often act counter to the field's vision of education. In confronting the multiple epistemological and pedagogical challenges Women's Studies faces as a 'discipline', Ballaster also addressed the 'productive tension' between teaching and learning in Women's Studies that is 'always under investigation in a politically self-conscious programme of study' (Ballaster, 2015). This political self-consciousness has been used by those both 'inside' and 'outside' the field of Women's Studies to question its longevity, its relevance and 'possibility' as both an academic and activist project.

\section{Women's Studies as an inclusive practice}

'It is easier to fight in the terrain of theory because it's never tested in the crucible of practice'. (Collins, 2015) ${ }^{4}$

Patricia Hill Collins (University of Maryland), in another keynote address at 'Teaching to Transgress', challenged the disconnect between the study of women's lived experience and the study of feminist theory. With reference to her field of Black Feminism in the US, she drew attention to the removal of women's lived experience and the tendency of scholars to retreat into the arguably 'safe' terrain of feminist theory. By reminding us of the very real, and even 'potential' implications and applications of our work in Women's Studies, including everyday priorities of work, family,

\footnotetext{
4 P. Hill Collins (2015), 'Still Brave? U.S. Black Feminism as a Social Justice Project', paper presented at 'Teaching to Transgress': Twenty Years of Women's Studies at Oxford conference, Oxford, 23 May 2015. Cited as (Hill Collins, 2015).
} 
education and health, Hill Collins encouraged the participants to readdress the relationship between the academic and the activist, the theorist and the practician, the political and the intellectual (Hill Collins, 2015). This includes showing an awareness about how our academic practice can be exclusive.

Writing of concerns surrounding 'exclusive knowledge' in Women's Studies, Eloise Buker claims that there is a 'structural contradiction between our claim to expertise and our vision of inclusion' (Buker, 2003: 87). If this is the case, it is important for us, as students and practitioners of Women's Studies, to question how we might resist traditional academic hierarchies, elitism and exclusivity in feminist knowledge-building, whilst also ensuring that the academy respects and values our scholarship. As Hill Collins argued in her paper, we must ask ourselves how contemporary feminist academia 'speaks' to contemporary women and, perhaps more importantly, how they may also 'speak to it'. While we can maintain inclusion and interdisciplinarity within the academy, fostering a relationship with feminist knowledge outside the academy is just as, if not more, important. She concludes that this involves 'reflexivities on our truths that we often carry through uncritically' (Hill Collins, 2015). Feminist scholars, in other words, must resist the belief that we are holders of 'superior' knowledge because we claim the feminist canon. We must not be complacent; we consider ourselves self-critical and socially conscious, but resting on the radical roots of the field can contribute to exclusivity.

This is particularly true when feminism, both academically and politically, is so often dominated by privileged women who even co-opt theories developed by marginalised women. The work of Women of Colour $(\mathrm{WoC})^{5}$, working-class women, as well as lesbian, gay, bisexual, transgender and other women with marginalised gender identities and sexual orientations, underpins much of the radical scholarship by which we, as Women's Studies scholars, are influenced and seek to advance. ${ }^{6}$ Recognising, valuing and supporting work by marginalised and underrepresented women is critical for progressive, radical and critical academic practice.

In her conference paper on the current position of Black Feminism in the US, Hill Collins warned against the 'symbolic' inclusion of a field of study

\footnotetext{
${ }^{5}$ WoC was coined in 1977 by the Black Women's Agenda at the National Women's Conference, Houston, Texas. The term is one of solidarity in the USA and other nations with a dominating white population.

${ }^{6}$ A key example of this, is black legal scholar Kimberlé Crenshaw's (1993) analytical concept of 'intersectionality' in 'Mapping the Margins'. Intersectionality is a feminist sociological theory that centres on analysing how oppressions intersect and has become the cornerstone for contemporary feminism. Crenshaw's role in advancing this theory, however, is often forgotten, misrepresented or undermined.
} 
made 'respectable'. This 'respectability', which is often a product of institutionalisation, she argued, often comes at the expense of the inclusion of 'real people'; it 'disappears the group' behind the field, placing it at the service of other paradigms (Hill Collins, 2015). This is a concern similarly expressed by Robyn Wiegman (Professor Literature and Women's Studies at Duke University) in her work on the possibility of Women's Studies. She argues that the move away from communitybased knowledges to academic institutionalisation poses a challenge for feminist theory, as it becomes 'hegemonic' at the expense of embracing their varieties (Wiegman 2001: 514-518). If practitioners of Women's Studies do not address the production and gatekeeping of a kind of 'exclusive' feminist knowledge, we ourselves run the risk of 'disappearing the group' (already a danger, as Hill Collins warned, in institutionalisation) and, therefore, 'disappearing' the politics underpinning Women's Studies' social relevance.

Women's Studies is political and intellectual, theoretical and practical, and this is not something from which we should seek to distance ourselves. One practical purpose of the discipline is to inform and interact with mass 'popular' feminism. In recent years, Sheryl Sandberg's book Lean In (2013) has received much public attention for its promotion of women in work and leadership, propagating what could be identified as 'trickle-down' feminist politics, rooted in a discourse of 'equality' (Sandberg, 2013). Critiquing Lean In's neoliberal or 'faux' feminist stance, the feminist intellectual and activist hooks identifies 'an academic subculture'-perhaps something of an 'echo chamber'-as the 'primary audience' for the work of those 'who have devoted lifetimes to teaching and writing theory' (hooks, 2013).

In this vein, Women's Studies faces a challenge in responding to what Angela McRobbie (Professor of Communications, Goldsmiths, University of London) calls the 'instrumentalising of feminism':

elements of feminism have been [...] absolutely
incorporated into political and institutional life. Drawing
on a vocabulary that includes words like
'empowerment' and 'choice,' these elements are then
converted into a much more individualistic discourse
and they are deployed in this new guise [...] as a kind of
substitute for feminism. (McRobbie 2009: 1)

In the context of Sandberg's success, hooks identifies the concern that campaigns and 'movements', such as Lean In, do not turn to 'primary sources' (i.e. feminist theorists) to broaden understanding. The result of this missed resource for Lean In includes a simplistic notion that feminism is about gaining 'equal' rights with men, simple categories (men 
and women) that have long been challenged by feminist thinkers. This is particularly relevant for black women and WoC who pioneer the study of intersectional identities and oppression structures (hooks, 2013). Instead of distancing ourselves from public discourse and practices of feminism, feminist scholars must engage more openly and more critically with diverse platforms, particularly social media, and in language that invites inclusion. As researchers, we have far more to gain by reaching across the perceived divide between academic and 'popular' feminism than we do by raising ourselves up as 'superior' holders of feminist knowledge, hiding in the academy or shying away in fear of being deemed 'irrelevant'.

In Oxford, the relationship between activism and academia is explored by students and staff. ${ }^{7}$ Passing on her own experience of academia and activism, Dr Dana Mills (Women's Studies 2014/15 mentor, Lecturer in Politics, Hertford College, University of Oxford) dedicated time to organising seminars with activists. This included a session with Ghada Rasheed from Women for Refugee Women, who encouraged participants to join in the 'Shut Down Yarls Wood' anti-detention action this year. ${ }^{8}$ Members of the cohort were also involved in extracurricular welfare and activist roles, including taking on positions as college Women's Officers and participating in university liberation campaigns including the LGBT (Lesbian, Gay, Bisexual and Transgender) and Women's Campaign. Further examples include a student's participation in the research panel organised by the Female Genital Mutilation NGO '28 Too Many' with Oxford Lawyers without Borders, and others organising, directing and acting in the documentary play Seven at Mansfield College, which tells the true stories of seven activist women. ${ }^{9}$

Bridging the gap between feminist academia and activism, a chasm that many academics and students already traverse, needs to be a priority for Women's Studies in Oxford and beyond. In the 1980s, hooks called for Women's Studies students to 'go into communities and discuss feminist issues door-to-door' to '[bridge] the gap between their educational experiences and the educational experiences of masses of women'. The principle of seeking out the 'group' in unconventional and proactive ways can help the activist/academic relationship, assist feminist movements and help Women's Studies students to grapple with the continued 'issue

\footnotetext{
7 The 'Rhodes Must Fall in Oxford' movement (co-founded by law student Ntokozo Qwabe), for example, began this year to decolonise the space, the curriculum, and the institutional memory within Oxford in connection with fighting intersectional oppression (A. Rhoden-Paul, 2015).

${ }^{8}$ See Guardian article 'Hundreds protest to demand closure of Yarl's Wood immigration centre' (M. Townsend, 2015).

${ }^{9}$ See Seven: A Documentary Play: http://seventheplay.com/.
} 
of whether or not their intellectual and scholarly pursuits are relevant to women as a collective group' (hooks 1984: 109).

\section{An impossible discipline?: the future of Women's Studies}

'... and we enter a politics without guarantees.' (Stuart Hall, 1997: 4)

Writing about Women's Studies at the turn of the twenty-first century, Wiegman declared that 'academic feminism had gone apocalyptic'. Yet this plaguing fear about the 'failure of the future' of the discipline was not a sudden manifestation (Wiegman, 2005: 40). Indeed, from its fledgling years in the late 1960s, Women's Studies has been hounded by a constant and anxious interrogation of its purpose, relevancy and even the very 'possibility' of its study. Despite the growth, however slow, of Women's Studies programmes, networks and journals in Europe, feminist academics such as Tania Modleski (1991) amongst numerous others, have persistently hailed the approaching worldwide demise of the discipline.

As the bells of academia's ivory towers toll the death of Women's Studies, our own anniversary celebrations did not shun the difficult selfquestioning that has dominated our discipline. Indeed, questioning the need to 'Call the whole thing off', Laura Doan (University of Manchester) opened her keynote by declaring that an anniversary offers us an important opportunity to critically reflect on our shortcomings. They allow us 'to pause,' to contemplate and 'to decide where the field will go next' (Doan, 2015). ${ }^{10}$

Twenty years of Women's Studies scholars at Oxford did not prevent us querying the sheer existence and 'possibility' of our subject. Might we follow Wendy Brown's poststructuralist critique of Women's Studies as a 'border control' of gender? (Brown, 1997: 79-101) Does its constitution of 'the discursively-produced and 'uncircumscribable "women"' as our object of study render our topic an incoherent 'impossibility'? (Brown, 1997: 83) Or, as Bonnie Zimmerman has suggested, might we champion the 'possibility' of Women's Studies to reassert the material reality of women's lives and institutionalised oppression, however diverse or 'incoherent'? (Zimmerman, 2005:31-39)

These debates of possibility and impossibility, of dualisms dividing our field, have troubled the global academy to crisis point. This can largely be attributed to the fear of Women's Studies' 'relevancy' when rooted

10 L. Doan (2015), 'The Impossibility/Possibility Debate: Let's Call the Whole Thing Off', paper presented at 'Teaching to Transgress': Twenty Years of Women's Studies at Oxford conference, Oxford, 23 May 2015. Cited as (Doan, 2015). 
within our discipline's very nomenclature. Widespread post-structuralist object-knowledge critiques, for example, have called for a non-unified, non-object-based discipline. Academic perceptions of Women's Studies have stayed true to this and remain largely embedded in the monolithic essentialisms and whitewashing of its radical feminist beginnings. However, in the process, Women's Studies, has undergone a profound mutation, often becoming a tacked-on suffix or superseded altogether'Women's Studies' has become 'Gender Studies'.11

Yet one might ask, 'what's in a name?' And indeed, for many, Gender Studies has largely represented Women's Studies by any other name. While the monetary resources for feminist scholarship and networks remain scarce and largely un-institutionalised, the broader scope of Gender Studies (perceived as 'non-restricted' and less of a 'minority group interest') has constituted a practical means of securing the financial future of Women's Studies within the academy. However, in expanding its purview, Gender Studies vitally represents the displacement of feminism and women from the core of our work. ${ }^{12}$ In this fundamental sense, the material reasoning governing the explicit engagement with women, whose omission from scholarship and teaching prompted the formation of Women's Studies, is ignored. Overlooking the totalising nature of patriarchy and the constraints placed upon women's collective academic as well as social action, the turn to Gender Studies risks the loss of women once more as 'a contested, visible and complex category of analysis' (Yee, 1997: 56). This turn omits a study that strives to validate the existence of women as a group within a patriarchal society and guarantees their presence within the academy as staff, student and subject.

Christina Crosby is apt to suggest that 'dealing with the fact of difference is the project of Women's Studies today' (Crosby, 1992: 131). The likes of Wendy Brown may critique Women's Studies as a striving for 'coherence', hailing the need for Gender Studies. Yet, as we have seen, it is a field that has consistently been one of contestation: of possibility and impossibility, of fluidity, instability and diversity. Despite the essentialist theories of our history, Women's Studies, like feminist thought, is one in which the mutating multiplicity of designations of 'woman', 'femininity' and 'gender' are interrogated in tandem with the multifarious oppressions which constitute the female experience. As Zimmerman

\footnotetext{
${ }^{11}$ Examples of this name change are legion, particularly in the USA. Equally, colleges such as Amherst (Massachusetts) have, in recent years, affixed 'Sexuality' and 'Gender Studies' to their Women's Studies programmes. Established in the 1970s, Amherst's Women's Studies programme is one of the oldest in the USA.

12 As Zimmerman writes: 'There is no Women's Studies without feminism [...] Feminism is what turns the study of women into Women's Studies. Gender studies might or might not be feminist [...] but Women's Studies must be feminist or it is not Women's Studies' (Zimmerman, 2005: 37).
} 
aptly notes, the 'woman' for whom Women's Studies presumes to study 'has always been conjectural, unfixed, slippery and contested' (Zimmerman, 2005: 34). Thus, what is ultimately at stake is the loss of the specific consideration of the lived category of 'woman' in all her contradictions and incompleteness.

Writing on the institutionalisation of deconstructive ideologies, Barbara Johnson notes that 'any discourse that is based on the questioning of boundary lines must never stop questioning its own' (Johnson, 1989: 13). Seeking to understand and ultimately deconstruct the boundary walls of the male/female hierarchy and, in turn, the institution of new fields of knowledge, Women's Studies is not immune to the need for such selfquestioning. The debates of possibility versus impossibility, of materialist versus discursive and of Women's Studies versus Gender Studies that have hounded our discipline from its very outset have persistently constructed, deconstructed, debated, challenged and revised its very underpinnings. At once possible and impossible, Women's Studies has never represented a stable or fixed location.

Opening the M.St core course with a consideration of the debates of possibility and impossibility, it is clear that Women's Studies as we know it, has embraced its polarisation. We have not been debilitated by division, as debate has brought with it strength and relevance. This is not limited to America and Europe, but is experienced in the development of Women's Studies globally. From their survey of Women's institutions, courses and academics across Tamil Nadu in India, Anandhi $\mathrm{S}$ and Padmini Swaminathan observe a 'palpable anxiety to be "relevant", which they claim is partially responsible for the shift from 'Women' to 'Gender' Studies particularly at the postgraduate level. In 2006, they noted the 'failure' of the founders of the discipline to 'achieve the kinds of intellectual and political changes promised'. Further linking the field to social development and justice, the Mother Teresa Women's University specifically states the necessity for research projects to be 'relevant to the needs of the times and [to] respond meaningfully to the demands of national development' (Anandhi S and Swaminathan, 2006: 4450).

\section{Conclusion}

We can see that Women's Studies is considered, often even by those who practice it, as different from other 'disciplines' or modes of inquiry. Researchers expect our work to contribute towards social change and frequently question why we are studying Women's Studies. This, however, is not a sign of instability, decline or failure. In fact, considering Women's Studies' commitment to challenging modes of knowing and 
valuing 'reflexivities on our truths', such critique and self-critique is a sign of success, of evolution and of growth.

Women's Studies has the potential to be transformative in academia and beyond. This potential, however, is defused when we try to 'assimilate Women's Studies to conventional academic parameters' (May, 2002: 144). Our relationship with the political, with activism, with feminism, cannot be compromised and certainly requires greater attention. One thing we may ask ourselves is what activism and social justice movements need from Women's Studies and other emancipatory fields of inquiry. What do they need from us and, crucially, can we provide it?

The feminist knowledge that we use, build and analyse must not be exclusive; it is based on the experience and contribution of women across history, races, ethnicities, nationalities, cultures, sexualities, abilities, complex gender identities, class and religions. These are the experiences with which we are aspiring to talk: complex, experiential knowledge that must be prioritised and amplified. In an age when some of the most radical, progressive and powerful feminist theory is being constructed and disseminated online and 'outside' institutionalised Women's Studies, we must listen.

We need not be threatened by the possible/impossible, theory/practice, intellectual/political dichotomies that have emerged over the past twenty years and been given so much attention. Indeed, they have necessarily challenged the field and brought about productive discussions as to how it can continue to develop and evolve. As Doan argued at the 'Teaching to Transgress' conference, 'we are a field posed to 'exploit rather than succumb to the edgy-ness of the impossibility and possibility debate' (Doan, 2015). As the discussions emerging from the conference showed, such a mantra can serve us well in an evolving field of study and aid us in resisting complacency.

\section{Acknowledgements}

'Teaching to Transgress': Twenty Years of Women's Studies at Oxford was generously sponsored by 'Women in the Humanities' (WiH), a programme for interdisciplinary humanities scholarship on women, within The Oxford Research Centre in the Humanities (TORCH). In addition to financial assistance, $\mathrm{WiH}$ also provided us with guidance and support. We are also grateful for the contributions made by Mansfield College, Kellogg College, the Philosophy Faculty, the Board for the M.St in Women's Studies, Rhodes Project, Oxford University Students Union (OUSU), Somerville College, St Peter's College and Wadham College, as 
well as our keynote and student speakers. Whilst organising a conference alongside our master's studies was a challenge, the interest garnered during this experience demonstrated how relevant the field remains and the varied scope of engagement across disciplines and the activist/academic divide. We are especially thankful for the immense support of Dr Dana Mills, the mentor for the M.St Women's Studies 2014/15 and to the whole of the M.St Women's Studies 2014/15 cohort for a year of friendship, feminism, solidarity and intellectual growth.

\section{Links to further resources from the event}

- Conference report at: http://torch.ox.ac.uk/teaching-transgresstwenty-years-womens-studies-oxford\#sthash.PNORjw5T.dpuf

- Podcasts: https://podcasts.ox.ac.uk/series/teaching-transgress

- Link to video: http://torch.ox.ac.uk/teaching-trangress

- Twitter: https://twitter.com/transgressconf

- Facebook page and event: www.facebook.com/teachingtotransgressconference; https://www.facebook.com/events/545361965606511/

\section{About Women in the Humanities (WiH)}

Women in the Humanities $(\mathrm{WiH})$ is the UK's major forum for interdisciplinary humanities scholarship on women. Established in 2013, and supported by The Oxford Research Centre in the Humanities (TORCH), WiH is bringing together scholars from across humanities disciplines to develop new approaches to women's equality. It has four aims:

- To create knowledge that develops new perspectives on gender equality.

- To train the next generation of pioneering women scholars, policymakers and professionals by supporting Oxford's Women's Studies Masters degree.

- To promote women's voice and influence within the humanities. WiH promotes working practices that allow women to thrive, providing a model of excellence for other institutions.

- To support the University in its promotion of gender equality, recognised by the Vice-Chancellor as a strategic aim for Oxford.

Since 2013, WiH has inaugurated and supported cross-disciplinary research into all aspects of women's lives, identities and representations through a programme of events open to academics, students and the 
public. Thanks to the generosity of an external donor, $\mathrm{WiH}$ has also been able to offer a number of funding opportunities for women in the humanities at Oxford to develop research ideas, write up research, hold events and conferences and develop teaching on women in the humanities.

WiH is co-directed by Professor Senia Paseta (History) and Professor Selina Todd (History). They are assisted by an advisory board and steering committee comprised of members in a range of disciplines at the University.

Further details and information about the work of WiH can be found on The Oxford Research Centre for the Humanities (TORCH) website: http://torch.ox.ac.uk/womenandhumanities

\section{References}

Papers cited from the 'Teaching to Transgress': Twenty Years of Women's Studies conference at Oxford, Mansfield College, 23 May 2015

Ballaster, R. (2015), 'Mastering Women's Studies? Habitus and Hazards'. Doan, L. (2015), 'The Impossibility/Possibility Debate: Let's Call the Whole Thing Off'.

Hill Collins, P. (2015), 'Still Brave? U.S. Black Feminism as a Social Justice Project'.

\section{Secondary Sources}

Anandhi S and Swaminathan, P. (2006), 'Making it Relevant: Mapping the Meaning of Women's Studies in Tamil Nadu', Economic and Political Weekly, 41 (42), 4444-4451

Brown, W. (1997), 'The Impossibility of Women's Studies', differences, $9(3), 79-101$

Buker, E. (2003), 'Is Women's Studies a Disciplinary or an Interdisciplinary Field of Inquiry?' National Women's Studies Association 15 (1), 73-93

Crenshaw, K. (1993), 'Mapping the Margins: Intersectionality, Identity Politics, and Violence Against Women of Colour', in Alcoff, L. M. and Mendieta, E. (eds.), Identities: Race, Class, Gender, and Nationality, Malden, MA: Blackwell Publishing

Crosby, C. (1992), 'Dealing with Differences' in Butler, J. and Scott, J. W. (eds.), Feminists Theorize the Political, New York, NY: Routledge, 130-143 
Hall, S. (1997), 'Race, the Floating Signifier,' Media Education Foundation http://www.mediaed.org/assets/products/407/transcript 407.pdf [accessed 14 September 2015]

hooks, b. (1984), Feminist Theory from Margin to Centre, Boston, MA: South End Press

--- (1994), Teaching to Transgress: Education as the Practice of Freedom, New York: Routledge

--- (2013), 'Dig Deep: Beyond Lean In', The Feminist Wire http://www.thefeministwire.com/2013/10/17973/7 [accessed 03 September 2015]

Johnson, B. (1989), A World of Difference, Baltimore, MD: The John Hopkins University Press

May, V. (2002), 'Disciplinary Desires and Undisciplined Daughters: Negotiating the Politics of a Women's Studies Doctoral Education', National Women's Studies Association, 14 (1), 134-159

McRobbie, A. (2008), The Aftermath of Feminism: Gender, Culture, and Social Change, London: SAGE

Modleski, T. (1991), Feminism without Women: Culture and Criticism in a "Postfeminist" Age (Japanese Studies), London: Routledge

Rhoden-Paul, A. (2015) 'Oxford Uni must decolonise its campus and curriculum, say students', The Guardian, 18 June 2015

http://www.theguardian.com/education/2015/jun/18/oxford-uni-mustdecolonise-its-campus-and-curriculum-say-students [accessed 10 October 2015]

Sandberg, S. (2013), Lean In: Women, Work and the Will to Lead, London: WH Allen

Townsend, M. (2015), 'Hundreds protest to demand closure of Yarl's Wood immigration centre', The Guardian, 6 June 2015 http://www.theguardian.com/uk-news/2015/jun/06/hundreds-protestat-yarls-wood-demand-closure [accessed 10 October 2015]

Wiegman, R. (2001), 'Women's Studies: Interdisciplinary imperatives, again,' Feminist Studies, 27 (2), 514-518

--- (2005), 'The possibility of Women's Studies' in Kennedy, E. and Beins, A. (eds.), Women's Studies for the Future: Foundations, Interrogations, Politics, Piscataway, NJ: Rutgers University Press, 40-60

Yee, S. (1997), 'The 'Women' in Women's Studies', differences, 9 (3), 4664 
Zimmerman, B. (2005), 'Beyond Dualisms: Some Thoughts about the Future of Women's Studies' in Kennedy, E. and Beins, A., Women's Studies for the Future: Foundations, Interrogations, Politics, Piscataway, NJ: Rutgers University Press, 31-39

\section{To cite this article:}

De Val \& Watson (2015). 'This is education as the practice of freedom': Twenty Years of Women's Studies at the University of Oxford, Exchanges: the Warwick Research Journal, 3(1), 112-127. Retrieved from: http://exchanges.warwick.ac.uk/index.php/exchanges/article/view/81 